DOI: https://doi.org/10.15688/nav.jvolsu.2021.1.12

UDC 902/904

LBC 63.4(2Poc.Кры)

Submitted: 17.09 .2020

Accepted: 27.05 .2021

\title{
MIDDLE SARMATIAN BURIAL COMPLEX FROM OPUSHKI NECROPOLIS, THE CRIMEA
}

\author{
Stanislav B. Shabanov \\ Non-Profitable Foundation "Heritage of Millennia", Simferopol, Russian Federation
}

\begin{abstract}
The Necropolis of Opushki is located in approximately $15 \mathrm{~km}$ to the east from Simferopol, 2-2,5 km to the south-west from the village of Opushki of Mazanka Rural Settlement in Crimea. Illegal excavations have been conducted on the territory of the cemetery since 2002. More than 200 burials constructions were destroyed as a result of grave robbers actions on the territory of about 3 hectares. Scientific researches of the necropolis were conducted in 2003 - 2005, 2007, 2009, 2013-2014, 2016-2020. During this period, more than 300 burials of different types have been uncovered (crypts, simple pit graves, shaft-and-chambers graves, slab graves and cist tomb). Judging by excavated sites, the cemetery was in continuous use from the $1^{\text {st }}$ century BC until the $4^{\text {th }}$ century AD. Among the researched burial constructions there are crypts typical for the Late Scythian period, middle and late Sarmatian burials, crypts influenced by the Northern Caucasus Alans arriving in Crimea, cremation performed by German tradition. The paper is devoted to the middle Sarmatian paired burial in the grave № 233 excavated in 2018. The assemblage of grave goods from that grave is quite various and informative: bronze fibulae, bronze and iron bracelets, red slip pottery, beads. The chronology of the burial assemblage may be defined as the second half of the $1^{\text {st }}$ - first half of the $2^{\text {nd }}$ centuries AD. The funeral rite of paired burials is not typical for the tradition of individual burials in first centuries, although its features are found in the burial grounds of the Central and South-Western Crimea. This funeral rite is associated with the issues of family structure and social relations in the late Scythian society.
\end{abstract}

Key words: Crimea, Opushki necropolis, Middle Sarmatian culture, paired burial, grave goods, glass vessel.

Citation. Shabanov S.B., 2021. Pogrebal'nyy kompleks srednesarmatskogo vremeni iz mogil'nika Opushki v Krymu [Middle Sarmatian Burial Complex from Opushki Necropolis, the Crimea]. Nizhnevolzhskiy Arkheologicheskiy Vestnik [The Lower Volga Archaeological Bulletin], vol. 20, no. 1, pp. 251-262. DOI: https://doi.org/10.15688/ nav.jvolsu.2021.1.12

\section{ПОГРЕБАЛЬНЫЙ КОМПЛЕКС СРЕДНЕСАРМАТСКОГО ВРЕМЕНИ ИЗ МОГИЛЬНИКА ОПУШКИ В КРЫМУ}

\section{Станислав Борисович Шабанов}

Благотворительный фонд «Наследие тысячелетий», г. Симферополь, Российская Федерация

Аннотация. Могильник Опушки расположен на расстоянии около 15 км к востоку от г. Симферополя, в 2-2,5 км к юго-западу от села Опушки Мазанского сельского поселения в Крыму. С 2002 г. на территории могильника ведутся грабительские раскопки. В результате действий грабителей было уничтожено более 200 погребальных сооружений на площади примерно 3 га. Научные исследования некрополя проводились в 
2003-2005, 2007, 2009, 2013-2014, 2016-2020 годах. За это время было открыто более 300 погребальных сооружений: склепов, грунтовых, подбойных и плитовых могил, каменный ящик. Судя по исследованным участкам, могильник беспрерывно использовался с I в. до н.э. по IV в. н.э. Среди погребальных сооружений встречаются склепы, характерные для позднескифской культуры, средне- и позднесарматские погребения, склепы, связанные с появлением в Крыму предков северокавказских алан, и кремация, совершенная по германскому обряду. Статья посвящена среднесарматскому парному погребению в могиле № 233, исследованному в 2018 году. Комплекс погребального инвентаря из могилы достаточно разнообразен и информативен: бронзовая фибула, бронзовые и железные браслеты, краснолаковая посуда, бусы. Погребальный комплекс может датироваться второй половиной I - первой половиной II в. н.э. Обряд парных захоронений не типичен для традиции индивидуальных погребений первых веков н.э., хотя и встречается в могильниках Центрального и Юго-Западного Крыма. Данный погребальный обряд связан с особенностями семейной структуры и социальных отношений в позднескифском обществе.

Ключевые слова: Крым, могильник Опушки, среднесарматская культура, парное погребение, погребальный инвентарь, стеклянный сосуд.

Цитирование. Шабанов С. Б., 2021. Погребальный комплекс среднесарматского времени из могильника Опушки в Крыму // Нижневолжский археологический вестник. Т. 20, № 1. С. 251-262. DOI: https://doi.org/ 10.15688/nav.jvolsu.2021.1.12

Могильник Опушки расположен в 2-2,5 км к юго-западу от одноименного села Мазанского сельского поселения Симферопольского района Республики Крым (рис. 1,a). Памятник был открыт грабителями в 2002 году. В результате их действий на площади около 3 га было уничтожено несколько сотен захоронений. Научные исследования могильника ведутся с перерывами с 2003 г. экспедицией Крымского федерального университета им. В.И. Вернадского. За время раскопок открыто более 300 погребальных сооружений: склепов, подбойных, плитовых и грунтовых могил, а также один каменный ящик с трупосожжением. Результаты исследований показали, что некрополь, относящийся к различным культурам, непрерывно использовался с I в. до н.э. до IV в. н.э. [Храпунов, 2019, c. 589], что делает его уникальным среди варварских погребальных памятников римского времени Предгорного Крыма. На так называемом позднескифском участке могильника в 2018 г. была открыта широкая грунтовая могила № 233 с парным погребением (рис. 1,б), относящимся к среднесарматскому периоду ${ }^{1}$.

Могила была ориентирована с северозапада на юго-восток. В юго-восточной части она прямоугольная в плане, в северо-западной - овальная. Ее размеры - 2,7 × 1,3 м, глубина - около 0,8 м. На дне могилы по длинной оси ямы параллельно друг другу были уложены два костяка в вытянутом положении на спине, головами на юго-восток.
В головах погребенных, у юго-восточной стены могилы, были установлены три краснолаковых сосуда (рис. $2,1,3,4$ ). В одном из них лежал стеклянный бальзамарий (рис. 2,2,3,5), в другом - кость животного, в третьем - еще один краснолаковый сосуд (рис. $2,5,3,1$ ) и нож (рис. 2,6, 3,14). Еще один железный нож (рис. 2,7, 3,13) был обнаружен возле этого скопления посуды.

У костяка I, уложенного вдоль северовосточной стены могилы, череп завалился вправо, ноги были немного разведены в коленях. В районе грудной клетки слева находилась бронзовая фибула (рис. 2,8,3,6), справа бронзовое кольцо с «шишечками» (рис. 2,9, 3,9 ) и бусы (рис. $2,10,3,15,16$ ), в районе живота - железный наконечник стрелы (рис. 2,11, $3,12)$. Слева от погребенного положили два камня.

Костяк II был уложен вдоль юго-западной стены могилы. Руки плотно прижаты к телу, а череп завалился вправо. На черепе (рис. $2,17,3,19$ ) и на месте левого плеча (рис. $2,18,3,17$ ) найдено по бусине. В районе грудной клетки (рис. 2,12, 3,10) и под правой ключицей (рис. 2, 16, 3,11) - по бронзовому кольцу с «шишечками». Под правым запястьем сохранился слой органического тлена коричневого цвета. В нем расчищены два браслета (рис. 2,13,14, 3,7,8) и бусина (рис. $2,15,3,18$ ). Могила была заполнена суглинком. Значительно позже прямо над могилой было совершено отдельное погребение лошади. 


\section{Погребальный инвентарь}

Краснолаковая посуда. На полу, за головами погребенных, были поставлены четыре краснолаковых сосуда: один кувшин и три чаши. Кувшин (рис. 3,1) (высота - 14,3 см, $d$ венчика -8 см, $d$ дна $-8,8$ см) на слабо выделенном кольцевом поддоне имеет тулово округлой формы, расширяющееся в средней части. Край венчика слегка подрезан. У кувшина дно несколько вогнуто, а в верхней части тулова имеется хорошо заметный валик. Ручка, уплощенная, прикреплена в средней части тулова так, что ее верхний прилеп закрывает валик. Подобные сосуды известны в Крыму в комплексах I - первой половины II в. н.э. [Высотская, 1994, табл. 35,5; Уженцев, 2006, рис. 86,5; Пуздровский, 2007, рис. $167,6,7,8$; Журавлев, 2010, с. 84-85, кат. 447-459; Медведев, 2010, рис. 1,2; Шапцев, 2014, рис. 4,11; Труфанов, 2014, рис. 10,1; Дашевская, 2014, табл. 168,9], но отличаются от опушкинского экземпляра более высоким кольцевым поддоном.

Чаша (рис. 3,2 ) (высота $-8 \mathrm{~cm}, d$ венчика $-16,2$ см, $d$ дна $-6,6$ см) на кольцевом поддоне имеет глубокое усеченно-коническое тулово, вертикальный бортик с двумя ручками-налепами в виде «бантика» и плоское дно, опускающееся к центру. Данная чаша находит аналогии в могильниках Бельбек IV [Журавлев, 2010, с. 59, кат. 191], Усть-Альма [Пуздровский, 2007, рис. 171,7], в крымских предгорьях и в некрополе Ново-Отрадное на Керченском полуострове [Арсеньева, 1970, табл. $15,11,13]$. Во всех случаях сосуды датируются серединой I - началом II в. н.э.

Глубокая чаша (рис. 3,4) (высота - 7,1 cм, $d$ венчика $-17,7$ см,$d$ дна $-8,4$ см) с туловом полусферической формы на кольцевом поддоне имеет почти вертикальные в верхней части стенки и заканчивается подрезанным изнутри венчиком. В Восточном некрополе Неаполя Скифского найдена подобная чаша в склепе, погребения в котором совершались в I-II вв. н.э. [Сымонович, 1983, табл. VIII,4]. Несколько более поздним временем (вторая половина II первая половина III в. н.э.) датируются такие чаши из могильников Бельбек IV [Журавлев, 2010, с. 54, кат. 157] и Битак [Пуздровский, 2007, рис. 182,7$]$.
Небольшая чаша (рис. 3,3) (высота $5,1 \mathrm{~cm}, d$ венчика $-10,6 \mathrm{~cm}, d$ дна $-5 \mathrm{~cm}) \mathrm{c}$ туловом полусферической формы на кольцевом поддоне имеет загнутые внутрь стенки. Близкие по форме сосуды происходят из погребальных комплексов второй половины I начала II в. н.э. Усть-Альминского некрополя [Пуздровский, Труфанов, 2017, рис. 156,1] и могильника Бельбек IV [Журавлев, 2010, с. 53, кат. 149].

Стеклянный бальзамарий. Небольшой сосуд (рис. 3,5 ) (высота $-6,2 \mathrm{~cm}, d$ венчика $0,8 \mathrm{~cm}, d$ дна -2 см) из тонкого прозрачного с голубым оттенком стекла имеет сферическое тулово, переходящее в короткое цилиндрическое горло. Край у бальзамария загнут, образовавшийся венчик отогнут и оплавлен. Дно сосуда вогнуто. У основания горла имеется перетяжка. К. Айсингс датировала небольшие бальзамарии с «шаровидным» туловом I в. н.э. [Isings, 1957, p. 22-23]. Такие сосуды, найденные на Боспоре, Н.З. Кунина и Н.П. Сорокина отнесли к флаконам 2-го типа по их классификации и датировали I - началом II в. н.э. [Кунина, Сорокина, 1972, с. 169]. У некоторых бальзамариев, происходящих из Северного Причерноморья, как и у опушкинского экземпляра, имеется перетяжка у основания горла [Алексеева, Сорокина, 2007, с. 63, табл. 41,5; Лимберис, Марченко, 2003, с. 144, рис. 25,25; Гущина, Журавлев, 2016, с. 162-163, табл. 130,5]. Небольшие стеклянные бальзамарии или флаконы с «шаровидным» туловом были широко распространены в первые века нашей эры и на территории Римской империи, и на ее периферии, но в Северном Причерноморье встречаются реже, нежели бальзамарии других форм.

Фибула. Небольшая бронзовая застежка (рис. 3,6) (длина 3,4 см) была сильно фрагментирована, но сохранила признаки, позволяющие отнести ее к лучковым подвязным одночленным фибулам группы 15 серии I варианта 2 по классификации А.К. Амброза [Амброз, 1966, с. 48-49] или группы 4 серии I варианта 2 по классификации В.В. Кропотова [Кропотов, 2010, с. 72, 74]. Такие фибулы получили распространение в период расцвета среднесарматской культуры и датируются второй половиной I - началом II в. н.э. [Пуздровский, 2007, с. 177; Кропотов, 2010, с. 74]. 
Браслеты. Один браслет был изготовлен из бронзы (рис. 3,7$)(d-7,2$ см) и имеет раскованные концы в виде стилизованных «змеиных головок». Браслеты такой формы пользовались большой популярностью у варварского населения Предгорного Крыма и являются частой находкой в погребальных комплексах I - первой половины III в. н.э. [Труфанов, 2001, с. 71-77, рис. 1; Пуздровский, 2007, с. 150]. Второй браслет (рис. 3,8 ) $(d-7,9$ см) представлял собой железный стержень, обмотанный бронзовой проволокой. Такие изделия в крымских предгорьях встречаются не часто. Аналогичные браслеты найдены в Опушках в склепе № 42, погребения в котором совершались в I в. до н.э. начале II в. н.э. [Храпунов и др., 2009, с. 13, рис. 28,1$]$, в Усть-Альминском некрополе, в комплексе конца I - первой половины II в. н.э. [Пуздровский, Труфанов, 2017, рис. 8,29] и могильнике Заветное. Последний найден в подбойной могиле второй половины II - первой половины ІІІ в. н.э. [Зайцев и др., 2007, рис. 20,12].

Кольиа с «иишечками». Три бронзовых литых кольца с многочисленными небольшими выступами (рис. $3,9-11)(d-7,9 ; 2,3 ; 2,3)$ относятся к широко распространенной в крымских предгорьях категории погребального инвентаря, фиксируемого в захоронениях I - середины III в. н.э. Происхождение и назначение таких изделий пока остается дискуссионным (см.: [Журавлев, 2014]).

Наконечник стрель. Железный трехлопастный черешковый наконечник стрелы (рис. 3,12$)(1,6 \times 1,0$ см) найден в районе груди костяка I. В крымских предгорьях такие наконечники встречаются в позднескифских комплексах первых веков нашей эры как в единичных экземплярах, так и в составе колчанных наборов [Пуздровский, 2007, с. 136-138].

В погребении также было найдено небольшое количество следующих бус:

- шаровидные поперечно сжатые из сердолика ${ }^{2}$ (2 экз.). Их размеры - 1,0 × 1,3 и $1,4 \times 1,0$ см (рис. 3,16). Камень полупрозрачный, ярко-оранжевого цвета, канал отверстия узкий, усеченно-конической формы. Сердоликовые бусы такой формы пользовались у населения крымских предгорий наибольшей популярностью в I-II вв. н.э. В III в. н.э. их количество сокращается, и ареал сужается до
Центрального и Юго-Западного Крыма [Стоянова, 2004, с. 291];

- шаровидная поперечно сжатая из гагата (1 экз.). $1,1 \times 1,7 \times 1,1 \mathrm{~cm}$ (рис. 3,15 ). Бусы такого типа в Северном Причерноморье бытуют на протяжении I-III вв. н.э., но встречаются и в более ранних комплексах [Алексеева, 1978, с. 10-11; Стоянова, 2004, c. 289-290];

- шаровидная поперечно сжатая из темного стекла (1 экз.). 1,2 × 1,1 см (рис. 3,19). Большая часть одноцветных шаровидных бус, найденных в Крыму, происходит из комплексов I-III вв. н.э. В погребениях IV в. н.э. они встречаются реже [Стоянова, 2004, с. 266; Алексеева, 1978, с. 62-65];

- шаровидная поперечно сжатая реберчатая из египетского фаянса белого цвета (1 экз.). D - 1,6 см (рис. 3,17). Такие бусы являются традиционными для погребальных комплексов раннеримского времени и первой половины III в. н.э. [Алексеева, 1975, с. 31; Стоянова, 2004, с. 288];

- шаровидная поперечно сжатая с широким каналом отверстия из иризированного стекла (1 экз.), 1,4 × 1,0 см (рис. 3,18).

Еще одна бусина из сильно иризированного стекла рассыпалась на фрагменты.

Захоронения в могиле № 233 можно отнести ко второй половине I - первой половине II в. н.э. и к среднесарматской культуре, на что указывает обряд парного погребения, характерный для сарматов первых веков нашей эры [Абрамова, 1959, с. 54-55; Пуздровский, Медведев, 2015, с. 256], и погребальный инвентарь, среди которого стоит выделить небольшой стеклянный бальзамарий. В раннеримское время в центральной части предгорий стеклянные сосуды встречаются крайне редко. Они известны только на городище и в некрополе Неаполя Скифского [Сымонович, 1983, табл. ХІІ, 2,6,11,15; Зайцев, 2003, рис. 109, 110], в могильниках Нейзац [Шабанов, 2011, рис. 11,69,70], Левадки ${ }^{3}$ и Опушки [Шабанов, 2020, рис. 1,1-5]. В то же время на синхронных варварских памятниках Юго-Западного Крыма стеклянной посуды IIII вв. н.э. на порядок больше, и разнообразие ее сопоставимо с коллекциями стекла из крупнейших античных центров Причерноморья. Пока сложно сказать, чем была вызва- 
С.Б. Шабанов. Погребальный комплекс среднесарматского времени из могильника Опушки в Крыму

на сложившаяся ситуация. С одной стороны, возможно, в центральной части крымских предгорий в скифо-сарматской среде стеклянные сосуды в погребальных обрядах использовались редко, с другой - местное варварское население могло и не иметь возможности по каким-то экономическим или иным причинам получать стеклянную посуду, например, из Херсонеса. Пока однозначно можно сказать, что в погребениях средесарматского времени к востоку от р. Альма стек- лянные сосуды, в сравнении с прочими античными импортами, встречаются значительно реже.

\section{ПРИМЕЧАНИЯ}

${ }^{1}$ Выражаю благодарность И.Н. Храпунову за возможность работы с неопубликованными материалами из могильника Опушки.

${ }^{2}$ Описание и определение бус А.А. Стояновой.

${ }^{3}$ Сообщение С.А. Мульда. 


\section{ИЛЛЮСТРАЦИИ}
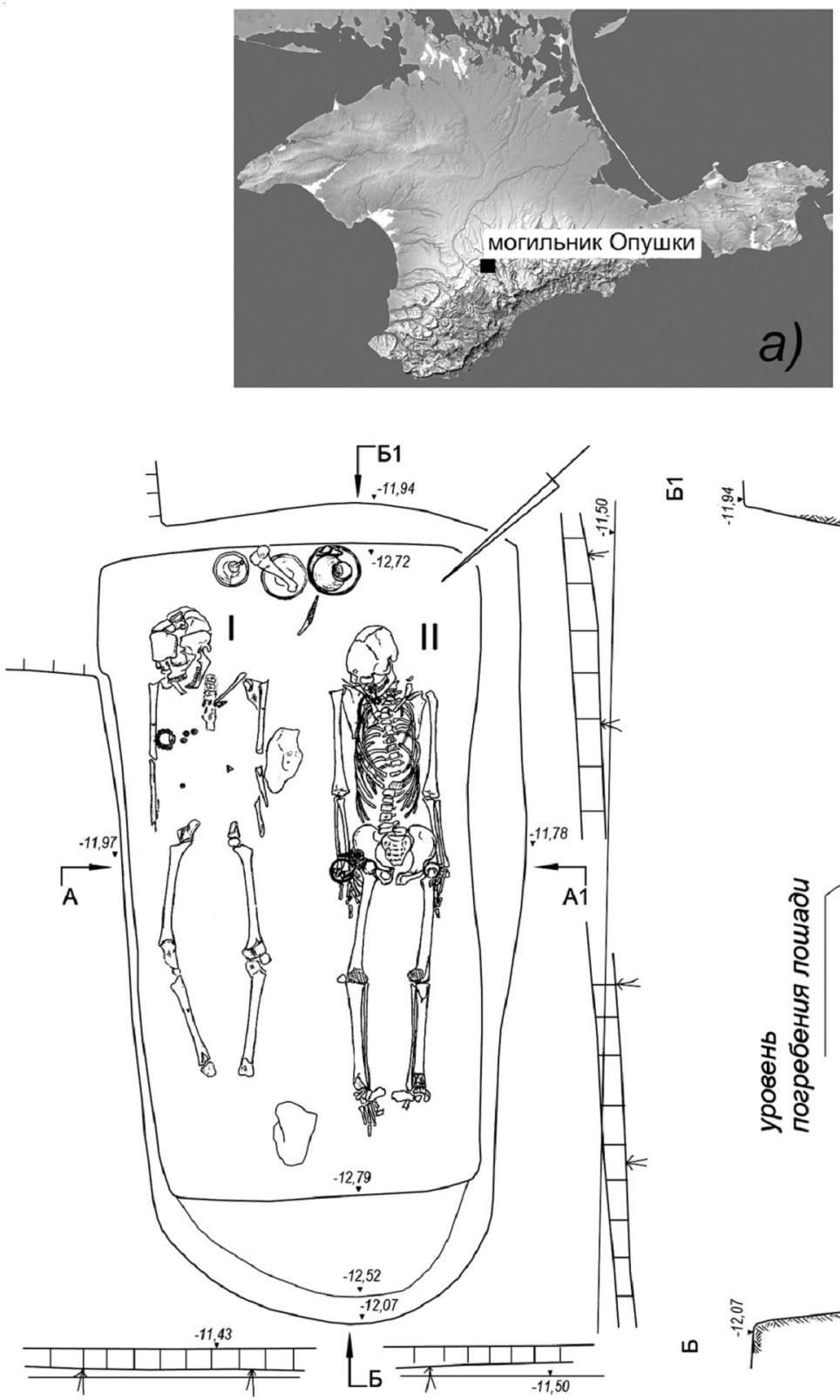

ธ

6)<smiles>C1CC2CCCC(C1)C2</smiles><smiles>[C]1C2CCCCC12</smiles>

\section{I, II - номера погребений}
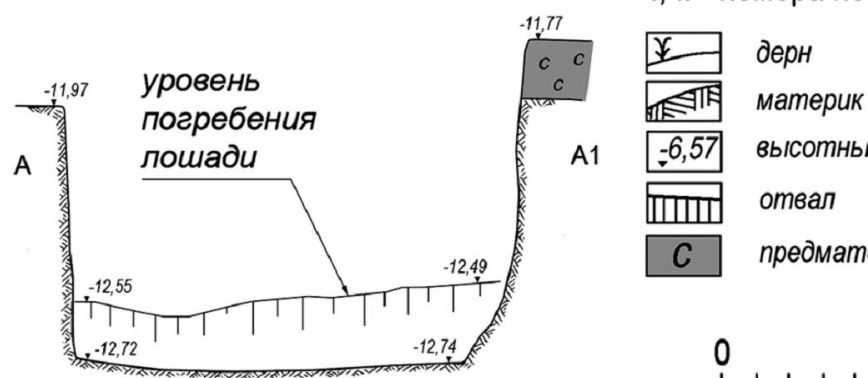

A1

\begin{tabular}{|ll}
\hline$-6,57$ & высотные отметки \\
\hline $\mathbf{W U}$ & отвал \\
\hline $\mathrm{C}$ & предматериковый суәлинок \\
\hline
\end{tabular}

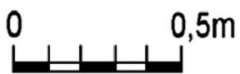

Рис. 1. Погребение среднесарматского времени из могильника Опушки (чертеж А.А. Стояновой): $a$ - месторасположение могильника Опушки; б - могила № 233

Fig. 1. The Middle Sarmatian time burial from the Necropolis of Opushki (drawing by A.A. Stoyanova): $a$ - location of the Necropolis of Opushki; $b$ - grave no. 233 
С.Б. Шабанов. Погребальный комплекс среднесарматского времени из могильника Опушки в Крыму

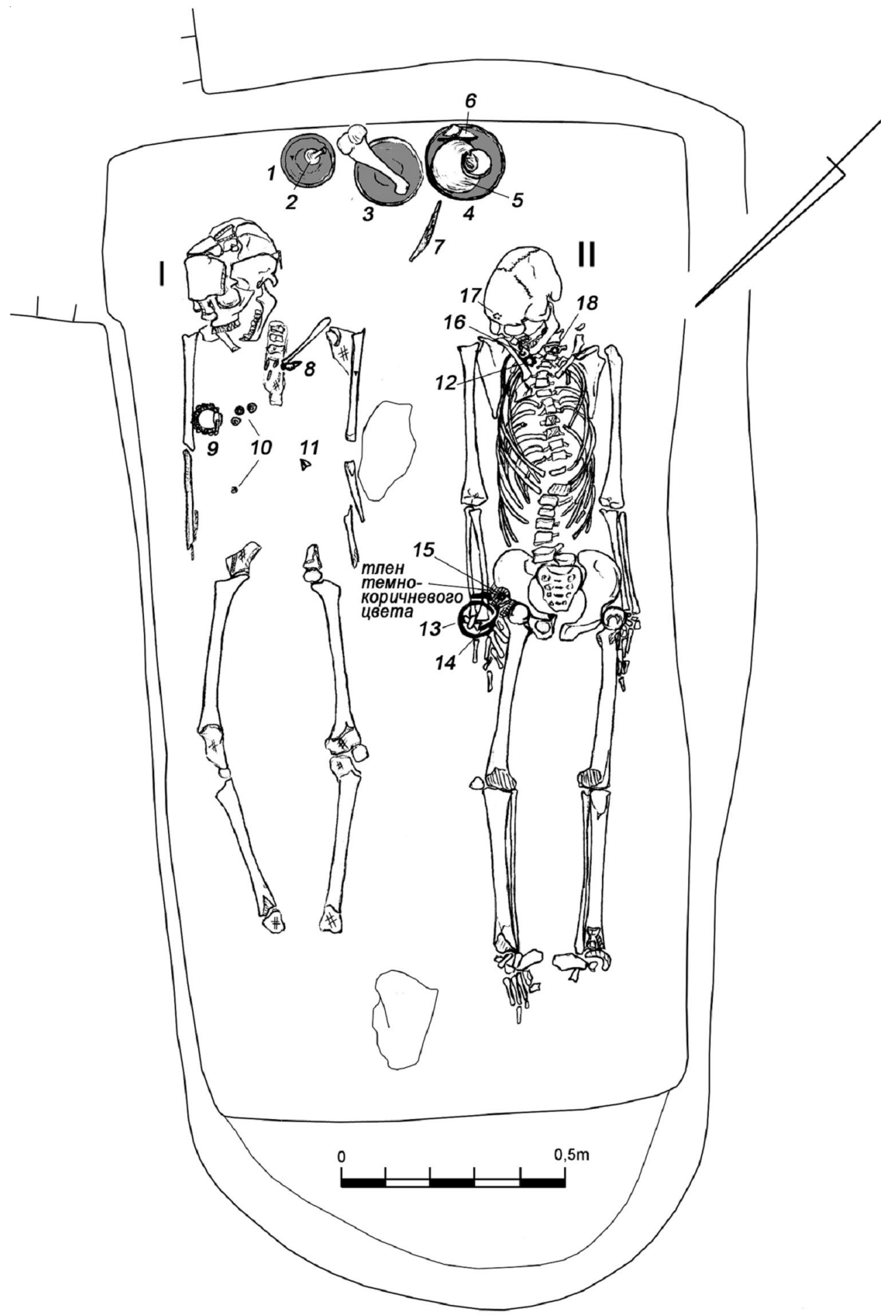

Рис. 2. Парное погребение в могиле № 233 могильника Опушки (чертеж А.А. Стояновой):

1, 3, 4 - чаши; 2 - бальзамарий; 5 - кувшин; 6, 7 - ножи; 8 - фибула; 9, 12, 16 - кольца с «шишечками»; $10,15,17,18$ - бусы; 11 - наконечник стрелы; 13, 14 - браслеты

Fig 2. Paired burial in grave no 233 of the Necropolis of Opushki (drawings by A.A. Stoyanova):

1,3,4 - cups; 2 - unguentarium; 5 - jug; 6, 7 - knives; 8 - brooch; 9, 12, 16 - knobby rings; $10,15,17,18$ - beads; 11 - arrowhead; 13,14 - bracelets 

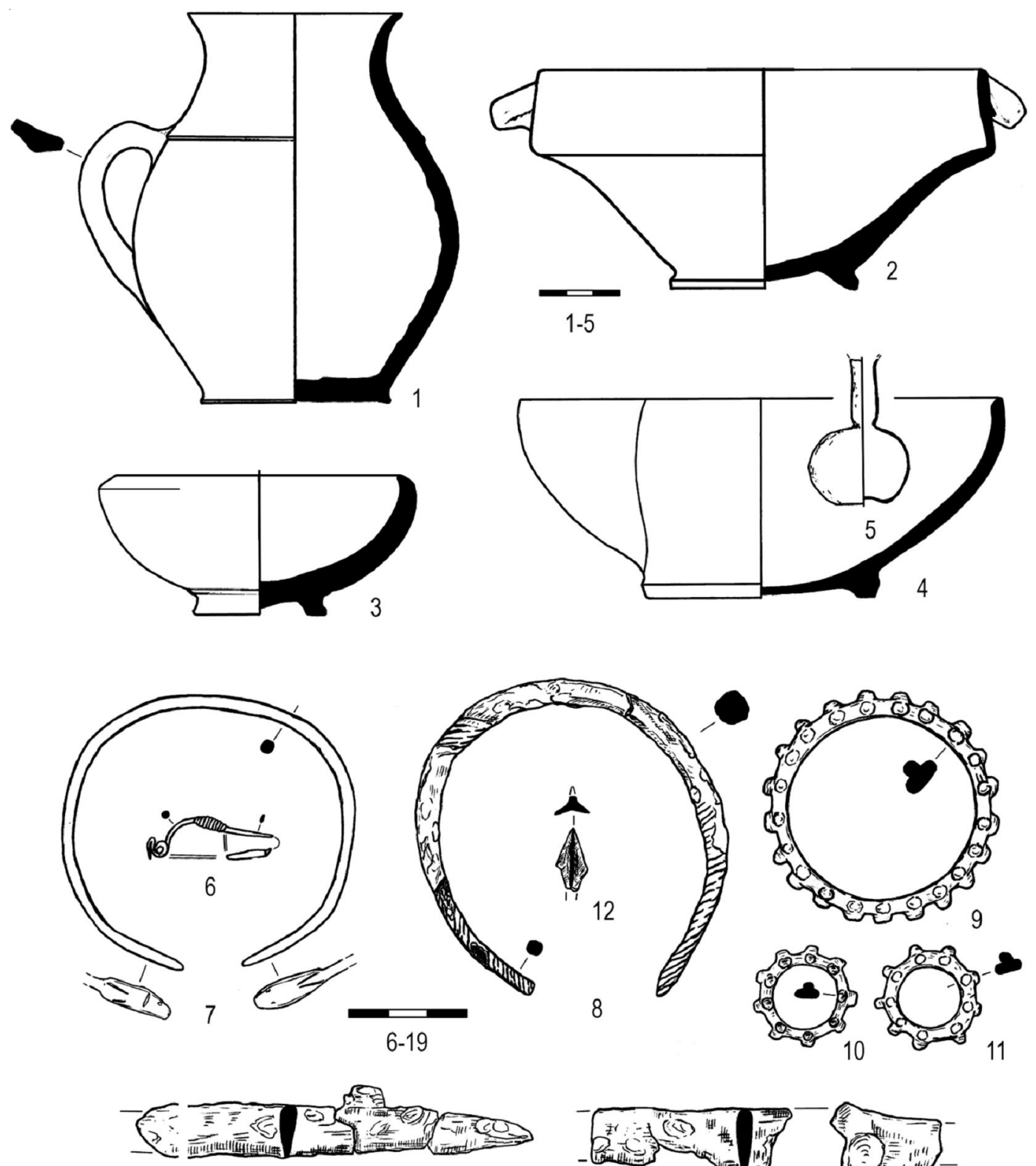

13

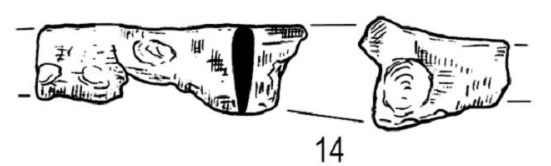

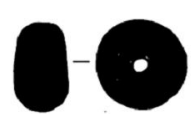

15

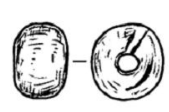

16

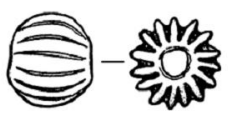

17

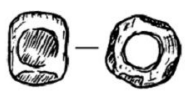

18

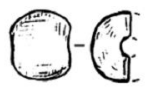

19

Рис. 3. Погребальный инвентарь из могилы № 233 могильника Опушки (рис. А.А. Стояновой, С.Б. Шабанова):

1 - кувшин; 2-4 - чаши; 5 - бальзамарий; 6- фибула; 7, 8- браслеты; 9-11 - кольца с «шишечками»; 12 - наконечник стрелы; 13, 14 - ножи; 15-19- бусы

Fig. 3. Grave goods from grave no 233 of the Necropolis of Opushki (drawings by A.A. Stoyanova, S.B. Shabanov):

1 - jug; 2-4 - cups; 5 - unguentarium; 6 - brooch; 7, 8- bracelets; 9-11-knobby rings; 12 - arrowhead; 13,14 - knives; $15-19$ - beads 


\section{СПИСОК ЛИТЕРАТУРЫ}

Абрамова М. П., 1959. Сарматская культура ІІ в. до н.э. - І в. н.э. // Советская археология. № 1. С. 52-71. Алексеева Е. М., 1975. Античные бусы Северного Причерноморья. Т. 1. САИ. Вып. ГІ-12. М. : Изд-во АН CCCP. $104 \mathrm{c}$.

Алексеева Е. М., 1978. Античные бусы Северного Причерноморья. Т. 2. САИ. Вып. ГІ-12. М. : Изд-во АН CCCP. 109 c.

Алексеева Е. М., Сорокина Н. П., 2007. Коллекция стекла античной Горгиппии. М. : Интербук-бизнес. 160 с.

Амброз А. К., 1966. Фибулы юга Европейской части СССР. САИ. Вып. Д1-30. М. : Изд-во АН СССР. 111 с.

Арсеньева Т. М., 1970. Могильник у д. Ново-Отрадное // Поселения и могильники Керченского полуострова начала н.э. Материалы и исследования по археологии СССР. № 155. М. : Наука. С. 82-149.

Высотская Т. Н., 1994. Усть-Альминское городище и некрополь. Киев : Киевская академия Евробизнеса. 208 с.

Гущина И. И., Журавлев Д. В., 2016. Некрополь римского времени Бельбек IV в Юго-Западном Крыму. В 2 ч. Ч. 2. М. : Исторический музей. 320 с.

Дашевская О. Д., 2014. Некрополь Беляуса. Симферополь : Феникс. 284 с.

Журавлев Д. В., 2010. Краснолаковая керамика Юго-Западного Крыма I-III вв. н.э. Симферополь. 320 с.

Журавлев Д. В., 2014. «Браслеты» и кольца с выступами из позднескифских и сарматских памятников Северного Причерноморья // Проблемы истории, филологии и культуры. № 1. С. 59-85.

Зайцев Ю. П., 2003. Неаполь Скифский (ІІ в. до н.э. - ІІІ в. н.э.). Симферополь : Универсум. 212 с.

Зайцев Ю. П., Волошинов А. А., Кюнельт Э., Масякин В. В., Мордвинцева В. И., Фирсов К. Б., Флесс Ф., 2007. Позднескифский некрополь Заветное (Алма-Кермен) 1-3 вв. н.э. в Юго-Западном Крыму. Раскопки 2004 г. // Древняя Таврика. Симферополь : Универсум. С. 249-290.

Кропотов В. В., 2010. Фибулы сарматской эпохи. Киев : АДЕФ-Украина. 384 с.

Кунина Н. 3., Сорокина Н. П., 1972. Стеклянные бальзамарии Боспора // Труды Государственного Эрмитажа. Т. ХІІІ. Л. : Аврора. С. 146-177.

Лимберис Н. Ю., Марченко И. И., 2003. Стеклянные сосуды позднеэллинистического и римского времени из Прикубанья // Материалы и исследования по археологии Кубани. Вып. 3. Краснодар : КГУ. С. $106-183$.

Медведев Г. В., 2010. Могилы с коллективными погребениями из Усть-Альминского некрополя // Древняя и средневековая Таврика. Археологический альманах. № 22. Донецк : Донбасс. С. 219-234.

Пуздровский А. Е., 2007. Крымская Скифия II в. до н.э. - III в. н.э. Погребальные памятники. Симферополь : Бизнес-Информ. $480 \mathrm{c}$.

Пуздровский А. Е., Медведев Г. В., 2015. Парные погребения первых веков н.э. на Усть-Альминском некрополе // История и археология Крыма. Вып. ІІ. Симферополь. С. 250-269.

Пуздровский А. Е., Труфанов А. А., 2017. Полевые исследования Усть-Альминского некрополя в 2000-2003 гг. Симферополь : ИП Зуева Т.В. 300 с.

Стоянова А. А., 2004. Бусы и подвески из могильника Нейзац (по материалам раскопок 1996-2001 гг.) // Боспорские исследования. Вып. V. С. 263-319.

Сымонович Э. А., 1983. Население столицы позднескифского царства (по материалам Восточного некрополя Неаполя Скифского). Киев : Наукова думка. 172 с.

Труфанов А. А., 2001. К вопросу о хронологии браслетов с зооморфными окончаниями (по материалам крымских могильников позднескифского времени) // Поздние скифы Крыма. Труды ГИМ. Вып. 118. М. : ГИМ. С. 71-77.

Труфанов А. А., 2014. Могильник I-ІІІ вв. н.э. у с. Холмовка и впускные погребения первых веков н.э. в курганах Юго-Западного Крыма // История и археология Крыма. Вып. І. Симферополь : БизнесИнформ. С. 183-209.

Уженцев В. Б., 2006. Эллины и варвары Прекрасной Гавани (Калос-Лимен в IV в. до н.э. - II в. н.э.) : Материалы по археологии Крыма. Симферополь : СОНАТ. 248 c.

Храпунов И. Н., 2019. Некоторые итоги и перспективы исследований варварских памятников римского времени в предгорном Крыму (на примере могильника Опушки) // XX Боспорские чтения. Боспор Ким- 
мерийский и варварский мир в период античности и средневековья. Основные итоги и перспективы исследований : материалы Междунар. науч. конф. Симферополь; Керчь. С. 589-592.

Храпунов И. Н., Мульд С. А., Стоянова А. А., 2009. Позднескифский склеп из могильника Опушки. Симферополь : Доля. $96 \mathrm{c}$.

Шабанов С. Б., 2011. Стеклянные сосуды из могильника Нейзац (по материалам раскопок 1996-2011 гг.) // Материалы по археологии, истории и этнографии Таврии. Вып. XVII. С. 141-191.

Шабанов С. Б., 2020. Стеклянные сосуды римского времени из могильника Опушки в Крыму (по материалам раскопок 2003-2019 гг.) // Проблемы истории, филологии и культуры. № 2. C. 110-134. DOI: https:// doi.org/10.18503/1992-0431-2020-2-68-110-134.

Шапцев М. С., 2014. Краснолаковая керамика из позднескифского городища Булганак // История и археология Крыма. Вып. І. Симферополь : Бизнес-Информ. С. 210-233.

Isings K., 1957. Roman Glass from Dated Finds. Groningen ; Djakarta : J.B. Wolters Publ. 185 p.

\section{REFERENCES}

Abramova M.P., 1959. Sarmatskaya kul'tura II v. do n.e. - I v. n.e. [Sarmatian culture in $2^{\text {nd }}$ century BC $-1^{\text {st }}$ century AD]. Sovetskaya arheologiya [Soviet Archeology], no. 1, pp. 52-71.

Alekseeva E.M., 1975. Antichnye busy Severnogo Prichernomorya [Antique Beads of the Northern Black Sea Region], vol. 1. Svod Arkheologicheskih Istochnikov, iss. ГI-12. Moscow, USSR Academy of Sciences. 104 p.

Alekseeva E.M., 1978. Antichnye busy Severnogo Prichernomorya [Antique Beads of the Northern Black Sea Region], vol. 2. Svod Arkheologicheskih Istochnikov, iss. ГI-12. Moscow, USSR Academy of Sciences. 109 p.

Alekseeva E.M., Sorokina N.P., 2007. Kollektsiya stekla antichnoy Gorgippii [The Collection of Glass of Ancient Gorgippia]. Moscow, Inerbuk-bisnes Publ. 160 p.

Ambroz A.K., 1966. Fibuly yuga Evropeyskoy chasti SSSR [Fibulae of South of European part of the USSR]. Svod Arkheologicheskih Istochnikov, iss. Д1-30. Moscow, USSR Academy of Sciences. $111 \mathrm{p}$.

Arseneva T.M., 1970. Mogilnik u d. Novo-Otradnoe [Cemetery Near Village of Novootradnoe]. Poseleniya i mogilniki Kerchenskogo poluostrova nachala n.e. [Settlements and Cemeteries of Kerch Peninsula of the Beginning of Common Era]. Materialy i issledovaniya po archaeologii SSSR, no. 155. Moscow, Nauka Publ., pp. 82-149.

Vysotskaya T.N., 1994. Ust'-Al'minskoe gorodishche i nekropol' [Ust-Alma Settlement and Necropolis]. Kiev, Kiev Academy Eurobusiness. 208 p.

Gushchina I.I., Zhuravlev D.V., 2016. Nekropol'rimskogo vremeni Bel'bek IVv Yugo-Zapadnom Krymu [Necropolis of the Roman Time Belbek IV in the South-Eastern Crimea]. Part 2. Moscow, SHM. 320 p.

Dashevskaya O.D., 2014. Nekropol' Belyausa [Necropolis of Belyaus]. Simferopol', Phoenix Publ. 284 p.

Zhuravlyev D.V., 2010. Krasnolakovaya keramika Yugo-Zapadnogo Kryma I-III vv. n.e. [Terra Sigillata of the South-Western Crimea in the 1st-3rd centuries AD]. Simferopol'. 320 p.

Zhuravlyev D.V., 2014. «Braslety» i kol'tsa s vystupami iz pozdneskifskih i sarmatskih pamyatnikov Severnogo Prichernomor'ya [Bracelets and Knobby Rings from Late- Scythian and Sarmatian Monuments of the Northern Black Sea Region]. Problemy istorii, filologii, kultury [Journal of Historical, Philological and Cultural Studies], no. 1, pp. 59-85.

Zaytsev Yu.P., 2003. Neapol' 'Skifskiy (II v. do n.e. - III v. n.e.) [Scythian Neapolis (II century B.C. - III century A.D.)]. Simferopol', Universum Publ. $212 \mathrm{p}$.

Zaytsev Yu.P., Voloshinov A.A., Kühnelt E., Masyakin V.V., Mordvintseva V.I., Firsov K.B., Fless F., 2007. Pozdneskifskiy nekropol Zavetnoe (Alma-Kermen) 1-3 vv. n.e. v Yugo-Zapadnom Krymu. Raskopki 2004 g. [The Late Scythian necropolis of Zavetnoe (AlmamKermen) of the $1^{\text {st }}-3^{\text {rd }} \mathrm{c}$. AD in the South-Western Crimea. Excavations of year 2004]. Drevnyaya Tavrika [Ancient Taurica]. Simferopol, Universum Publ., pp. 249-290.

Kropotov V.V., 2010. Fibuly sarmatskoy epokhi [Fibulae of the Sarmatian Epoch]. Kiev, ADEF-Ukraine Publ. 384 p. Kunina N.Z., Sorokina N.P., 1972. Steklyannye balzamarii Bospora [Glass Balsamaria of the Bosporus]. Trudy Gosudarstvennogo Ermitazha [Proceedings of the State Hermitage], iss. XIII. Leningrad, Aurora Publ., pp. 146-177.

Limberis N.Yu., Marchenko I.I., 2003. Steklyannye sosudy pozdneellinisticheskogo i rimskogo vremeni iz Prikuban'ya [Glass Vessels of Late Hellenistic and Roman Times from Kuban Area]. Materialy $i$ issledovaniya po 
arkheologii Kubani [Materials and Researches on Archaeology of the Kuban Region], iss. 3. Krasnodar, KubSU, pp. 106-183.

Medvedev G.V., 2010. Mogily s kollektivnymi pogrebeniyami iz Ust'-Al'minskogo nekropolya [Graves with "Collective" Burials from Ust -Alma Necropolis]. Drevnyaya i srednevekovaya Tavrika. Arheologicheskij al'manah [The Ancient \& Medieval Taurica. Archeological Almanac], no. 22. Donetsk, Donbass Publ., pp. 219-234.

Puzdrovskiy A.E., 2007. Krymskaya Skifiya II v. do n.e. - III v. n.e. Pogrebal'nye pamyatniki [Crimean Scythia II Century BC - III Century AD. Burial Monuments]. Simferopol', Bisnes-Inform Publ. 480 p.

Puzdrovskiy A.E., Medvedev G.V., 2015. Parnye pogrebeniya pervyh vekov n.e. na Ust'-Al'minskom nekropole [Paired Burials of the First Centuries AD the Necropolis of the Ust-Alma]. Istoriya $i$ arheologiya Kryma [History and Archaeology of Crimea], vol. II. Simferopol', pp. 250-269.

Puzdrovskiy A.E., Trufanov A.A., 2017. Polevye issledovaniya Ust'-Al'minskogo nekropolya v 2000-2003 gg. [Field Studies of the Ust-Alma Necropolis in 2000-2003]. Simferopol', IP Zueva T.V. Pupl. 300 p.

Stoyanova A.A., 2004. Busy i podveski iz mogil'nika Neyzats (po materialam raskopok 1996-2001 gg.) [Beads from Neizats Cemetery (on Materials of Excavations in 1996-2001)]. Bosporskiye issledovaniya [Bosporos Studies], vol. V, pp. 263-319.

Symonovich E.A., 1983. Naselenie stolitsy pozdneskifskogo tsarstva (po materialam Vostochnogo nekropolya Neapolya Skifskogo) [The Population of the Capital of the Late Scythian Polity (According to the Materials from the Eastern Cemetery of Scythian Neapolis]. Kiev, Naukova Dumka Publ. 172 p.

Trufanov A.A., 2001. K voprosu o khronologii brasletov s zoomorfnymi okonchaniyami (po materialam krymskikh mogilnikov pozdneskifskogo vremeni) [On the Issue about Chronology of Bracelets with Zoomorphic Endings (after Materials of Crimean Cemeteries of the Late Scythian Period)]. Pozdnie skify Kryma [The Late Scythians of the Crimea]. Trudy Gosudarstvennogo Istoritcheskogo Muzeya, iss. 118. Moscow, SHM, pp. 71-77.

Trufanov A.A., 2014. Mogil'nik I-III vv.n.e. u s. Holmovka i vpusknye pogrebeniya pervyh vekov n.e. v kurganah Yugo-Zapadnogo Kryma [Necropolis of I-III Century A.D. at v. Holmovka and Inlet Burials of the First Centuries A.D. in the Burial Mounds of South-West Crimea]. Istoriya i arheologiya Kryma [History and Archaeology of Crimea], vol. I. Simferopol', Bisnes-Inform, pp. 183-209.

Uzhentsev V.B., 2006. Elliny i varvary Prekrasnoy Gavani (Kalos Limen v IV v. do n.e. - II v.n.e.): Materialy po arkheologii Kryma [Hellenes and Barbarians of the Perfect Harbor (Kalos Limen in the $4^{\text {th }}$ Century BC $2^{\text {nd }}$ Century AD): Materials on the Archaeology of the Crimea]. Simferopol, SONAT. 248 p.

Khrapunov I.N., 2019. Nekotorye itogi i perspektivy issledovaniy varvarskikh pamyatnikov rimskogo vremeni v predgornom Krymu (na primere mogil'nika Opushki) [Some Results and Prospects of Research of Barbarian Monuments of the Romena Time in the Piedmont Crimea (on the Example of Opushki Burial Ground)]. XX Bosporskie chteniya. Bospor Kimmeriyskiy i varvarskiy mir v period antichnosti i srednevekov'ya. Osnovnye itogi $i$ perspektivy issledovaniy: materialy Mezhdunarodnoj nauchnoj konferencii [XX Bosporan Readings. Cimmerian Bosporus and the World of Barbarians in Antiquity and the Middle Ages. Main Results and Prospects of Research. Materials of International Scholarly Conference]. Simferopol', Kerch', pp. 589-592.

Khrapunov I.N., Muld S.A., Stoyanova A.A., 2009. Pozdneskifskiy sklep iz mogilnika Opushki [A Late Scythian Vault from the Cemetery of Opushki]. Simferopol, Dolya Publ. 96 p.

Shabanov S.B., 2011. Steklyannye sosudy iz mogil'nika Neizats (po materialam raskopok 1996-2011 gg.) [Glass Vessels from Neizats Cemetery (on the Materials of Excavations in 1996-2011)]. Materialy po arkheologii, istorii $i$ etnografii Tavrii [Materials in Archaeology, History and Ethnography of Tauria], vol. XVII, pp. 141-191.

Shabanov S.B., 2020. Steklyannye sosudy rimskogo vremeni iz mogil'nika Opushki v Krymu (po materialam raskopok 2003-2019 gg.) [Glass Vessels from the Roman Period in Opushki Necropolis, the Crimea (Excavations in 2003-2019)]. Problemy istorii, filologii, kultury [Journal of Historical, Philological and Cultural Studies], no. 2, pp. 110-134. DOI: https://doi.org/10.18503/1992-0431-2020-2-68-110-134.

Shaptsev M.S., 2014. Krasnolakovaya keramika iz pozdneskifskogo gorodishcha Bulganak [Red Slip Pottery from the Late Scythian Settlement Bulganak]. Istoriya i arheologiya Kryma [History and Archaeology of Crimea], vol. I. Simferopol', Bisnes-Inform Publ., pp. 210-233.

Isings K., 1957. Roman Glass from Dated Finds. Groningen, Djakarta, J.B. Wolters Publ. 185 p. 


\section{Information About the Author}

Stanislav B. Shabanov, Project Manager, Non-Profitable Foundation "Heritage of Millennia", Chernishevskogo St, 10a, office 6, 295051 Simferopol, Russian Federation, neizats2004@mail.ru, https://orcid.org/0000-0002-1450-9292

\section{Информация об авторе}

Станислав Борисович Шабанов, руководитель проектов и программ, Благотворительный фонд «Наследие тысячелетий», ул. Чернышевского, 10а, оф. 6, 295051 г. Симферополь, Российская Федерация, neizats2004@mail.ru, https://orcid.org/0000-0002-1450-9292 